Published by LPMP Imperium

Journal homepage: https://ejournal.imperiuminstitute.org/index.php/JMSAB

\title{
ARE LEGAL ASPECTS, NEW NORMAL (COVID-19), AND ENTREPRENEURIAL CHARACTERISTICS IMPORTANT FOR THE GROWTH OF HIGHER EDUCATION INDUSTRY PERFORMANCE IN DKI JAKARTA?
}

\author{
Prasetio Ariwibowo ${ }^{*}$, Haryanto ${ }^{2}$, Taufik ${ }^{3}$ \\ ${ }^{123}$ Economics Education Study Program, Faculty of Science and Social \\ Education, Indraprasta University PGRI Jakarta \\ Email Korespondensi: *Prasetioariwibowo87@gmail.com
}

\begin{abstract}
This research is a quantitative research conducted to find out how big and how important is the role of business legality, New Normal (Covid-19) and the entrepreneurial character of an entrepreneur, especially on business performance in the form of market share, profitability, and business productivity, especially in the business sector of universities in Indonesia. DKI Jakarta. Determination of the sample was carried out by purposive sampling with a sample of 150 respondents consisting of lecturers, students, and several university officials in DKI Jakarta. In this study using SEM-PLS as a test analysis tool. The results of this study indicate that the entrepreneurial characteristics of business actors have a vital role in the growth of business performance, while the legal aspect of business does not have a significant influence in improving the performance of higher education institutions in DKI Jakarta, both from the point of view of profitability, market share, and business productivity.
\end{abstract}

Keywords: Characteristics, Entrepreneurship, Higher Education, Legal Aspects, New Normal (Covid-19), Performance

Jurnal

Manajemen

Strategi dan

Aplikasi

Bisnis,

Vol 4, No. 2,

2021,

pp. 553 - 561

eISSN 2655-

237X

CC BY: This license allows reusers to distribute, remix, adapt, and build upon the material in any medium or format, so long as attribution is given to the creator. The license allows for commercial use. 


\section{INTRODUCTION}

In this modern era, which is fully modern, dynamic, self-service, and always requires us to always be fast moving and routinely use technology in our daily life, some questions sometimes arise, namely, are the legal aspects and the entrepreneurial character of nature and science still important? studied and developed in running a business to achieve maximum performance in entrepreneurship, ranging from achieving business productivity, profitability, to market share growth in various business sectors, especially for business actors in the field of universities in DKI Jakarta.

Entrepreneurship is an activity to increase a person's level of welfare in the future. This level of welfare can be achieved when business actors dare to take risks, maximize their time, and produce various products and services that are able to provide solutions to various problems for the community. This means that every individual who has normal skills can become an entrepreneur as long as each individual has the desire and has the opportunity to learn and do business by taking advantage of the business ideas and business opportunities that have been created.

In the science of entrepreneurship, there are many aspects that must be considered by each individual when forming or setting up a business, one aspect that must be considered is the legal aspect. Business and law cannot be separated like business with other components. In addition to the law contains the meaning of rules that can be enforced to regulate relations between humans and between humans and their communities, business also contains the understanding of the overall business activities carried out by people or entities on a regular and continuous basis, namely in the form of activities to procure goods or services. services and facilities to be traded, exchanged or leased for the purpose of making a profit.

Then how important is it from the legal aspect in starting or running a business??, the status of a legal entity is an important basis when we start running a business, therefore the company must have a certain legal entity in order to have legality in carrying out its activities. The existence of a corporate legal entity will protect the company from all claims due to the activities it carries out. Because corporate legal entities provide business certainty, so that concerns over legal violations can be anticipated, or avoided considering that corporate legal entities have signs that must be obeyed. By having a legal entity, the company will fulfill the obligations and rights of various parties related to the company, both within the company and outside the company.

\section{LITERATURE REVIEW}

\section{Characteristics of Entrepreneurship}

A characteristic is a particular distinguishing feature or quality, a distinctive feature of a person or thing. Characteristics of entrepreneurship can be interpreted as something related to the characteristics, character, behavior, character, and attitudes of people towards the struggle of life to achieve inner and outer happiness. The characteristics of entrepreneurship or entrepreneurship are continuous or eternal qualities or traits that can be found in the attitudes or actions taken by an entrepreneur. These attitudes and actions usually cover a large part of the attitude of an entrepreneur in his daily life and are attitudes and actions that are carried out in everyday life. Successful entrepreneurs can be seen from their daily attitudes, including having commitment and not being half-hearted in doing a job. He also dares to take calculated risks and dares to take even the slightest opportunity. According to M. Scarborough and Thomas W. Zimmeree as quoted by Suryana (2013).

In Islam, the characteristics of entrepreneurship (Buchari, Alma, 2006), include the nature of piety, trust, remembrance, and gratitude, honesty, waking up at dawn and working, tolerance, tithing and giving.

\section{Business Law}

We can define law as rules of behavior that can be applied/applied to regulate the relationships between humans and between humans and their communities. We can 
understand law as: "a set of principles and rules imposed by the state to regulate behavior and/or applied by judges to settle cases as well as a means of social control and a means in an effort to meet the generally accepted needs of society to seek justice and stability. " (Henry Campbell, 1991) The notion that places the state as having a constitutional role and duty to protect citizens is currently being tested. Currently consciously or not, planned or spontaneously, have been involved in the process of transformation towards a world ruled by neoliberal capitalism, this is where the concept of the welfare state is being tested to provide welfare for citizens. The tradition of state intervention that characterizes the concept of "welfare state" has changed. Economic issues have developed in such a way that hopes and concerns arise as well as the emergence of a new era, in which the role and involvement of state organizations will gradually decrease in many aspects of socio-economic life. (Coughlin, Paulee, 1994) The principle of law is a meta-rule that is behind the rules, which contains value criteria which to be able to guide behavior requires elaboration or concretization into legal rules. In the dynamics of legal life in society, the legal principles serve to determine the area of application of the rule of law in the interpretation or discovery of law, as a critical rule of the rule of law, the rule of judge in determining the legitimacy of the rule of law, the rule that unites the rules or norms. - the rule of law, maintaining/maintaining the consistency and coherence of the rule of law. Material obedience (material stelselmatigheid) in the legal system refers to the order of legal principles that underlies and animates the legal order. The order of legal principles is the foundation of the legal order. Therefore, legal principles can be identified by generalizing judges' decisions and by abstracting from a number of legal rules related to the same social problem. M. Daud Silalahi (2001), which states that environmental law enforcement includes compliance and enforcement which includes state administrative law, civil law and criminal law fields.

\section{New Normal Covid-19}

The spread of the Corona Virus in Indonesia (Covid-19) with the number of cases and/or the number of deaths has increased and spread across regions and across countries and has an impact on the political, economic, social, cultural, defense and security aspects, as well as the welfare of the people in Indonesia. The Corona virus then appeared and gave so much influence in various sectors. One of the sectors that was affected and felt so much was the economic sector (Burhanuddin, 2020). The spread of Covid-19 has made the world restless, including in Indonesia. Covid-19 is a new type of virus so many people don't know and don't understand how to deal with the virus. Along with the outbreak of the corona virus or covid19 to hundreds of countries, the government of the republic of Indonesia provided a health protocol. The health protocol will be implemented throughout Indonesia by the government with centralized guidance by the ministry of health. In fact, a number of regions that have implemented PSBB are considered ineffective for various reasons. According to the sociologist, Imam Prasodjo, the inhibiting factors for the implementation of the PSSB are public awareness, many offices that should be closed but not closed, still require work, distribution of basic necessities that are not smooth, legal approach that is not serious (Prasojo, 2020). Donald Back argues that the effectiveness of the law is the main problem in the sociology of law which is obtained by comparing the legal reality in theory with the legal reality in practice so that there appears to be a gap between the two (Sukananda, 2018). New Normal was implemented after the first phase of PSBB and the second phase ended, new normal became an option for several reasons, including the reasons for implementing PSBB in the first phase causing a decrease in state income and increasing poverty rates. According to the Head of the Expert Team for the Task Force for the Acceleration of Handling Covid-19, Wiku Adisasmita, New Normal is a change in behavior to continue carrying out normal activities, but coupled with the application of health protocols to prevent the transmission of Covid19. (Indonesia.go.id, 2020). Until the end of the second phase of PSBB implementation, the policy for implementing the New Normal has not been regulated in laws and regulations, but in fact the implementation of the New Normal has been desired by the community as a balanced solution in preventing COVID-19 and fulfilling economic needs. 


\section{Hypothesis}

the following hypothesis can be formulated:

H1: Legal aspects affect the performance of higher education institutions.

H2: Entrepreneurial character has an effect on higher education performance.

H3 : New Normal (Covid-19) has an effect on higher education performance.

\section{METHOD}

This research is an explanatory research, which explains the influence between the variables and the relationship between the variables studied. Time to collect data from SMEs in a cross-sectional manner. The population is the entire group of people or events that will be measured quantitatively with certain characteristics as the object of research. The study population was 150 academics from various universities in DKI Jakarta randomly, each member of the population had the same chance of being selected as a sample. From each selected academic community, there are lecturers, university officials, to students at various universities in DKI Jakarta as informants/respondents with consideration because they are familiar with various university academic operational activities because they determine policies and are responsible for business continuity. Primary data collection through questionnaires filled out by respondents directly.

To analyze the relationship between variables using variance Based Structural Equation Modeling (SEM-PLS), each variable is assumed to represent a concept in the form of a latent variable. In Wold (1985) as quoted by (Lin et al., 2020) the Partial Least Square (PLS) method can test the relationship between variables even though the data are not normally distributed in multivariate and explain whether or not there is a relationship between latent variables with a relatively small sample size (at least 30 respondents). In addition, PLS is also able to analyze constructs formed with reflexive and formative indicators, which is different from SEM data analysis because there will be an unidentified model.

In processing data using SEM-PLS is more complicated, because SEM is built by a measurement model and a structural model. The definition of the structural model or what is known as the inner model is a model that connects latent variables. While the measurement model or outer model is a measurement model that connects the indicator with its latent variables.

Based on the hypotheses and background that have been compiled, the research design of Based on these matters this study is:

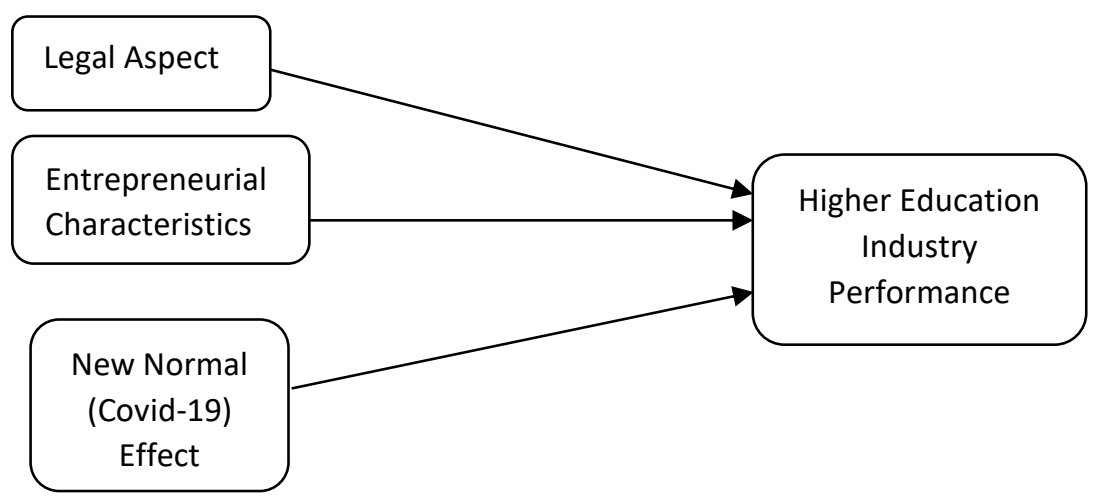

Figure 1. Framework Hypotesis 


\section{RESULT AND DISCUSSION}

Table 1. Latent Variable Correlations

\begin{tabular}{lllll}
\hline Variable & $\begin{array}{l}\text { Entrepr } \\
\text { eneurial } \\
\text { Characte } \\
\text { ristics }\end{array}$ & $\begin{array}{l}\text { Legal } \\
\text { Aspe }\end{array}$ & $\begin{array}{l}\text { New } \\
\text { Normal } \\
\text { (Covid- } \\
19) \\
\text { Effect }\end{array}$ & $\begin{array}{l}\text { Higher } \\
\text { Educati } \\
\text { on } \\
\text { Industr } \\
\text { y } \\
\text { Perfor } \\
\text { mance }\end{array}$ \\
\hline $\begin{array}{l}\text { Entreprene } \\
\text { urial } \\
\text { Characteris } \\
\text { tics }\end{array}$ & 1,00 & 0,413 & 0,177 & 0,001 \\
\hline $\begin{array}{l}\text { Legal } \\
\text { Aspect }\end{array}$ & 0,41 & 1,000 & 0,290 & $-0,086$ \\
\hline $\begin{array}{l}\text { New } \\
\text { Normal } \\
\text { (Covid-19) }\end{array}$ & 0,17 & 0,290 & 1,000 & 0,072 \\
Effect & 7 & & & \\
\hline $\begin{array}{l}\text { Higher } \\
\text { Education }\end{array}$ & 0,00 & $-0,086$ & 0,072 & 1,000 \\
$\begin{array}{l}\text { Industry } \\
\text { Performanc } \\
\text { e }\end{array}$ & & & & \\
\hline
\end{tabular}

According to table 1, the calculation results from this study are values that indicate the relationship of variables to other variables. Because in this case the dependent variable is Higher Education Industry Performance. From this column, it can be seen that the highest value was contributed by Legal Aspect, each of which was 0.413 . This shows that of all the independent variables in this study, the legal aspect has the highest influence on Higher Education Industry Performance. Legal aspect is associated with Higher Education Industry Performance by $41.3 \%$.

\section{Table 2. R Square}

\begin{tabular}{ll}
\hline Variable & R-Square \\
\hline Operating Income Performance & 0,604 \\
\hline
\end{tabular}

The results of the study in table 2 show how much the independent variable in this study can explain the dependent variable under study. The dependent variable in this study is Higher Education Industry Performance, so the row used in the table is the Higher Education Industry Performance row. From the table, it can be seen in the Legal Aspect and Entrepreneurial Characteristics lines, the value is 0.604 . This means that in this study, both before and after the COVID-19 pandemic, Legal Aspect and Entrepreneurial Characteristics could explain 60\% of Higher Education Industry Performance, and the remaining $40 \%$ was explained by other variables outside the study. This, when referring to the research method, means that the model in this study is strong/high because the value is above 0.50 .

To see whether the hypothesis is accepted, the T-Statistic value can be seen, if the T-Statistic value is above 1.96 then the hypothesis is accepted and if the T-Statistic value is below 1.96 then the hypothesis is rejected. To see the direction of the effect, you can see the value of the original sample, if the original sample shows a negative number, then the effect is negative, if the original sample shows a negative number. 
shows a positive number, then the effect is positive. To see whether the effect is significant or not, it can be seen from the $P$ Values, if the P Values are below 0.05 then the effect is significant and if the $P$ Values are above 0.05 then the effect is not significant.

Table 3. Total Effects

\begin{tabular}{|c|c|c|c|}
\hline & $\begin{array}{l}\text { Original } \\
\text { Sample } \\
\text { (0) }\end{array}$ & $\begin{array}{l}\text { T Statistics } \\
(\mid 0 / \text { STDEV|) }\end{array}$ & $\begin{array}{l}\mathrm{P} \\
\text { Values }\end{array}$ \\
\hline \multicolumn{4}{|l|}{ Direct Effect } \\
\hline $\begin{array}{l}\text { Entrepreneurial } \\
\text { Characteristics - } \\
\text { > Higher } \\
\text { Education } \\
\text { Industry } \\
\text { Performance } \\
\end{array}$ & 0,372 & 5,653 & 0,000 \\
\hline $\begin{array}{l}\text { Legal Aspect -> } \\
\text { Higher } \\
\text { Education } \\
\text { Industry } \\
\text { Performance }\end{array}$ & 0,232 & 2,891 & 0,004 \\
\hline $\begin{array}{l}\text { New Normal } \\
\text { (Covid-19) } \\
\text { Effect -> Higher } \\
\text { Education } \\
\text { Industry } \\
\text { Performance }\end{array}$ & $-0,103$ & 1,160 & $-0,247$ \\
\hline
\end{tabular}

\section{Discussion}

Based on table 3 regarding the value of hypothesis testing, it can be seen that the influence of Entrepreneurial Characteristics on Higher Education Industry Performance has a T-Statistic value of 5.653 with an original sample of 0.372 and a P Value of 0.00 . This means that hypothesis 1 is accepted, that is, every academic community, especially the bad character of the leadership or the rector or the foundation of a university, turns out to have a strong enough influence on the fundamental performance of a university. With a positive original sample value and a $p$ value of 0.00 . This means that if the leadership or rector or foundation of a university has good or bad character in providing services to students and employees of the university, there will be an increase and decrease in Higher Education Industry Performance which is positive and significant for the academic community of the university. in DKI Jakarta. Similarly, in table 3 regarding the value of hypothesis testing, it can be seen that the influence of Legal Aspect on Higher Education Industry Performance has a T-Statistic value of 2.891 with an original sample of 0.232 and a P Value of 0.004 . This shows that hypothesis 2 is accepted, which means that there is a not-so-large but strong legal influence on Higher Education Industry Performance at universities in DKI Jakarta. This is reinforced by the results of research conducted by (Al-ayuby, 2020), if the principles of accountability for business actors for losses suffered by consumers (students and graduates / I at various academic levels) are associated with higher education activities at state universities and private sector, students can claim the responsibility of higher education administrators (organization bodies and university management) on the following grounds:

1. There is an error in the form of an unlawful act based on Article 1365 of the Civil Code or negligence based on Article 1366 of the Civil Code and/or caused by the actions of people who are their dependents based on Article 1367 of the Civil Code, where the organizers of the PT (University) have violated the rights of students as consumers who its provisions are spread across various laws and regulations related to consumer protection and higher education. 
2. The existence of implied warranties, especially related to the level of quality or promises regarding educational services offered by private universities to students.

3. The principle of strict liability can be used as a basis for prosecution if there is a causal relationship between the defect in educational products (diplomas) and student losses. For example, when the College and/or Study Program are not accredited; and/or individuals, organizations, or higher education providers who without the right to issue academic degrees and vocational degrees, then based on the provisions of Article 28 of Law Number 12 of 2012 concerning Higher Education "the title is declared invalid and revoked by the Minister."

In relation to research conducted by researchers, it can be concluded that if the principles of responsibility (Entrepreneurial Characteristics and Legal Aspects) of business actors for losses suffered by consumers are associated with higher education implementation activities, students can claim the responsibility of the Higher Education Organizing Body even though does not rule out the possibility of higher education managers can also be held accountable. Therefore, for all activities of university administration that are detrimental to students, in the perspective of consumer protection law, those responsible for the loss are the organizing body in the form of a foundation, association, or association as a business actor. Where the compensation value demanded can be taken from the assets of the organizing body, even though the compensation is not given.

However, behind these various conditions, the higher education industry in DKI Jakarta, both before and during the Covid-19 pandemic, remains in an optimistic condition. It is shown in table 3 that the value of hypothesis testing is known together that the influence of the New Normal (Covid-19) on the Industrial Performance of Higher Education has a T-Statistic value of 1,160 with an original sample of -0.103 and a $P$ Value of -0.247 thus indicating that hypothesis 3 rejected, which means that there is no large and not strong (not significant) effect of New Normal (Covid-19) on the Performance of Higher Education Industry at Higher Education in DKI Jakarta. This is supported by the results of research conducted by Elfian, Ariwibowo, and Johan (2017), that it is estimated that the condition of education in DKI Jakarta in particular will experience better development than it is now. To achieve this positive development will face various challenges from this progress.

\section{Conclusion}

Based on the results of research and discussion, the researchers made conclusions related to the research objectives, namely:

1. Entrepreneurial Characteristics towards Higher Education Industry Performance has a TStatistic value of 5.653 with an original sample of 0.372 and a P Value of 0.00 . This means that hypothesis 1 is accepted, that is, every academic community, especially the bad character of the leadership or the rector or the foundation of a university, turns out to have a strong enough effect on the fundamental performance of a university in DKI Jakarta.

2. New Normal (Covid-19) Effect have a not too large effect on Legal Aspect but are strong enough on Higher Education Industry Performance, which has a T-Statistic value of 2.891 with an original sample of 0.232 and a P Value of 0.004 . This shows that hypothesis 2 is accepted, which means that there is an influence of Legal Aspect on Higher Education Industry Performance at universities in DKI Jakarta.

Based on the results of research that has been done, research can provide input to:

1. Academic Community

The parties as policy makers should have the characteristics of an entrepreneur in the field of education who has a "parent" mindset and mentality, so that they can provide good and correct examples for other academic community parties who are not policy makers, both verbally and verbally. writing to maintain the same culture and spirit from bottom to top management in order to realize the progress of higher education in accordance with 
the vision and mission of the company/organization/university in DKI Jakarta.

In achieving an increase in the productivity of higher education performance in the face of fundamental conditions in running a business, the rector/policy makers at a university should pay attention to increasing production factors (number of classes, qualified teaching and learning activity system/curriculum/syllabus both online and offline). offline, laboratories for various study programs, and other factors of production), production equipment and supplies, and efficiency through work systems aimed at improving production processes. Second, to meet these objectives, the quality of human resources must be improved, namely through periodic education and training for the middle to bottom management. Third, to improve business competitiveness (starting from recruitment, process to output for employees, lecturers, and students every period). Fourth, it is strived to ensure the availability of capital with simple procedures and close to the location, the availability of funds for innovation steps. Fifth, always make improvements in terms of management and legal aspects both offline and online

2. Other researchers

For researchers who intend to conduct similar research more broadly and in depth, they should examine and examine other factors related to government subsidies, the characteristics of entrepreneurs in the field of education, other internal business factors, to factors from the legal aspect in carrying out and developing business in the field of education, especially in higher education.

\section{REFERENCES}

Aidis, R., \& van Praag, M. (2007). Illegal entrepreneurship experience: Does it make a difference for business performance and motivation? Journal of Business Venturing, 22(2), 283-310. https://doi.org/10.1016/j.jbusvent.2006.02.002

Alma, Buchari. (2009). Kewirausahaan. Bandung: Alfabeta.

Al-ayuby, F. (2020). Aspek - Aspek Hukum Perlindungan Konsumen Dalam Penyelenggaraan Perguruan Tinggi Swasta Di Indonesia. Badamai Law Journal, 5(1), 102-121.

Bileviciene, T., \& Bileviciute, E. (2012). The Legal Aspects of University Management Development. Universitetū Valdymo Tobulinimo Teisiniai Aspektai., 2012(3), 140-150. http://escweb.lib.cbs.dk/login?url=http://search.ebscohost.com/login.aspx?direct=true\&db=sih\& $\mathrm{AN}=83377985 \&$ site $=$ ehost-live.

Black, Henry Campbell. (1991). Black's Law Dictionary. St. Paul, MN: West Publishing Co.

Burhanuddin, C.I., \& Abdi, M.N. (2020). Krisis Ekonomi Global dari dampak Penyebaran Virus Corona. Akmen: Jurnal Ilmiah. Vol. 17(1). 90-98. Available at https://ejurnal.stienobelindonesia.ac.id/index.php/akmen/article/vi ew/866/823

Coughlin, Paulee, A. (1994). I. introduction. Ind. Int'l \& Comp. L. Rev, 5/143(HeiOnline), 143169.

https://heinonline.org/HOL/LandingPage?handle=hein.journals/iicl5\&div=10\&id=\&p age $=$

Elfian, E., Ariwibowo, P., \& Johan, R. S. (2018). Peran Pendidikan Tinggi dalam Meningkatkan Minat Masyarakat untuk Produktivitas Pendidikan. Sosio E-Kons, 9(3), 200-215.

Indonesia.go.id. (2020). Mengenal Konsep New Normal. Available at https://indonesia.go.id/ragam/komoditas/e konomi/mengenal-konsep-new-normal 
Li, Z., \& Liu, Y. (2011). Entrepreneurship education and employment performance. Journal of Chinese Entrepreneurship, 3(3), 195-203. https://doi.org/10.1108/17561391111166975

Lin, H. M., Lee, M. H., Liang, J. C., Chang, H. Y., Huang, P., \& Tsai, C. C. (2020). A review of using partial least square structural equation modeling in e-learning research. British Journal of Educational Technology, 51(4), 1354-1372. https://doi.org/10.1111/bjet.12890.

Prasodjo, Imam. (2020). Ungkap Faktor Penghambat Pelaksanaan Pembatasan Sosial Ber skla Besar (PSBB). DOI : https://youtu.be/0EBWUy4RSic.

Silalahi, M. Daud. (2001). Hukum lingkungan dalam sistem penegakan hukum di Indonesia. Bandung : Alumni Bandung.

Simatupang, Batara M., (1996). "Strategi Memenangkan Persaingan di Era Pasar Bebas," Usahawan, 25 (09): 46-49. September.

Sukananda, Satria. (2018). Pendekatan Teori Hukum Progresif dalam Menjawab Permasalahan Kesenjangan Hukum (legal gaps) di Indonesia. Jurnal Hukum Ekonomi Syariah. 1(2).135-158. Available at http://www.jurnalnasional.ump.ac.id/index .php/JHES/article/view/3924, pp 147

Suryana. (2013). Kewirausahaan Kiat dan Proses Menuju Sukses. Jakarta: Salemba Empat.

Viinikainen, Jutta; Heineck, Guido; Böckerman, Petri; Hintsanen, Mirka; Raitakari, O., \& Pehkonen, J. (2017). Born entrepreneurs? : Adolescents' personality characteristics and entrepreneurship in adulthood. .. Journal of Business Venturing Insights, 8, 9-12. https://doi.org/https://doi.org/10.1016/j.jbvi.2017.05.001

\section{Author Profiles}

Prasetio Ariwibowo is a professional lecturer at the Economic Education study program at Indraprasta University, PGRI Jakarta. Author 1 is also a researcher who is starting to become a consultant in the field of MSME management, and cooperatives. Currently the author 1 is completing his doctoral studies in the final stages at one of the leading universities in Malaysia.

Haryanto is a lecturer at the Economic Education study program at Indraprasta University, PGRI Jakarta, and Deputy Dean of the Faculty of Science and Social Education, Indraprasta University, PGRI Jakarta, in addition, the second author is the owner of a well-known Cargo Logistics company in Indonesia, and the second author is in the process completed his doctoral studies at Borobudur University, Jakarta until now.

Taufik is the Dean of the Faculty of Science and Social Education, Indraprasta University, PGRI Jakarta. The third author is also a lecturer as well as a legal expert or legal consultant in the field of education and non-education.

\section{Correspondence.}

The author in writing this scientific publication article can be contacted via email: Prasetioariwibowo87@gmail.com 